\title{
Current concerns in haematology 1 Is the painful crisis of sickle cell disease a "steal" syndrome?
}

\author{
G R Serjeant, R M Chalmers
}

\section{Introduction}

All genotypes of sickle cell disease are characterised by recurrent attacks of pain, which are most frequent and most severe in homozygous sickle cell disease and sickle cell $\beta^{\circ}$ thalassaemia. The pain may be localised to the abdomen but the causes of most abdominal painful crises are unknown. Bone pain is much more common, and results from avascular necrosis of the bone marrow, as evidenced by the aspiration of necrotic bone marrow from sites of pain,,$^{1-5}$ the behaviour of bone marrow on scintigraphy, ${ }^{2-6}$ and the close correlation between the sites of pain and that of erythropoietically active bone marrow. In children below the age of 5 years, active bone marrow occurs in the metacarpals, metatarsals, and phalanges, and avascular necrosis results in the characteristic dactylitis or handfoot syndrome. At older ages, active marrow disappears from peripheral bones to become localised in the juxta-articular areas of long bones, and the clinical picture of dactylitis is replaced by the classic painful crisis. In this the most common sites of pain are the long bones, spine, and joints, the latter usually resulting from the long bones adjacent to the joint being affected.

If active erythropoiesis with its high metabolic and oxygen demands is one of the essential conditions of the painful crisis, what precipitates the avascular necrosis? An acute increase in oxygen demand must be unlikely and it is presumed to follow a fall in oxygen delivery. This reduced delivery is usually attributed to the vaso-occlusion characteristic of sickle cell disease, and the terms painful crisis and vaso-occlusive crisis are often used interchangeably. Observations which are inconsistent, or difficult to reconcile with this interpretation, include the role of skin cooling in precipitating crises, the bilateral symmetry of pain, and the failure of factors inhibiting sickling to reduce the number of painful crises.

Medical Research Council Laboratories, The University of the West Indies, Mona, Kingston, Jamaica G R Serjeant

R M Chalmers

Correspondence to: Professor G R Serjeant Accepted for publication 28 March 1990

\section{Precipitating factors}

Painful crises are episodic and most Jamaican patients recognise clear precipitating factors which precede painful crises. Contrary to what might be expected, these are not factors such as lowered oxygen tension and acidosis, which under laboratory conditions promote sickling.

The commonest precipitating factor, recognised by 200 Jamaican patients with sickle cell disease in a recent questionnaire study, was skin cooling which was volunteered by $74 \%$ of patients and admitted on direct questioning in $90 \%$ of patients. Seasonal patterns of painful crises have been reported in Jamaica ${ }^{7}$ and elsewhere. ${ }^{8-10}$ There is evidence that this may be a direct result of skin cooling, ${ }^{11} 12$ and getting caught in the rain or swimming in the sea or a river were volunteered in $24 \%$ and $13 \%$ and admitted on direct questioning in $50 \%$ and $40 \%$, respectively. The association of exposure to cold and bone pain is less obvious in North America and Europe where "manipulation" of environment is more common: air conditioning in the summer and central heating in the winter diminish the apparent seasonal effect. Exposure in northern climates is further reduced by warm clothing, whereas in Jamaica patients tend to wear a thin shirt regardless of the climate and the skin is more directly exposed to environmental temperature.

In the Jamaican questionnaire other precipitating factors included exercise (volunteered by $47 \%$, obtained on direct questioning in $66 \%$ ), infections $(2 \%$ and $24 \%$, respectively), and psychological stress (9\% and $22 \%$, respectively). These are broadly similar to precipitating factors observed elsewhere, ${ }^{8}$ although their prevalence and the proportion where no factor was recognised has varied between studies.

As cold is the most important precipitating factor in the Jamaican environment it is on this that the ensuing discussion will focus in the development of a new hypothesis for the painful crisis.

\section{Bilateral symmetrical pain}

The distribution of bone pain in many painful crises is bilateral and symmetrical, affecting both knees, both ankles, and both shoulders. Many Jamaican patients volunteer that pain affects symmetrical joints either simultaneously or within a period of less than six hours. The blood supply to the bone marrow of one distal femur could be impaired by a vaso-occlusive event, but were this a truly random process, the chances of involvement of the contralateral femur should be no greater than any other bone or joint. Even a general increase in circulating sickled, or less deformable, red cells might explain the simultaneous onset of bone pain at random sites but not the symmetrical pattern so frequently observed. 


\section{Factors inhibiting sickling}

FETAL HAEMOGLOBIN CONCENTRATION

Fetal haemoglobin persists for longer in sickle cell disease and higher concentrations are associated with less sickling and generally less severe clinical disease. ${ }^{13-15}$ Although $\mathrm{HbF}$ molecules inhibit the growth of polymers of deoxy HbS molecules and although high concentrations of $\mathrm{HbF}$ are associated with low, irreversibly sickled cell counts, ${ }^{16}$ patients with high $\mathrm{HbF}$ concentrations may experience frequent severe bone pains while others with low concentrations rarely develop pains. Populations characterised by high $\mathrm{HbF}$ concentrations such as in central India and the eastern province of Saudi Arabia, have painful crises as a major symptom ${ }^{17} 18$ although other features are often benign. Finally, statistical analyses of the incidence of painful crisis and $\mathrm{HbF}$ concentrations in both the United States of America and Jamaica failed to show any protective effect of high $\mathrm{HbF}$ concentrations. ${ }^{19} 20$

EFFECT OF GENOTYPES OF SICKLE CELL DISEASE Sickle cell $\beta^{\circ}$ thalassaemia and the interaction of sickle cell disease with homozygous $\alpha^{+}$ thalassaemia are both associated with a lower mean corpuscular haemoglobin concentration and are therefore less likely to manifest intravascular sickling. Red cell survival is prolonged in sickle cell disease with homozygous $\alpha^{+}$thalassaemia. ${ }^{21}$ Persistence of splenomegaly as well as other indices of clinical improvement occur in both genotypes, but neither the number nor severity of painful crises is reduced. ${ }^{22}{ }^{23}$ Indeed, there is some anecdotal evidence that the frequency of pains may be increased.

\section{CYANATE TREATMENT}

Sodium cyanate carbamylates $\mathrm{HbS}$ and inhibits its polymerisation, reducing sickling and improving red cell survival, but this agent failed to reduce painful crises in a double blind cross-over study. ${ }^{24}$

All of the above conditions seem to inhibit sickling yet have no discernible effect on the numbers of painful crises. In each case the reduction in sickling has been attended by an increase in total haemoglobin concentration which is a risk factor for painful crisis. ${ }^{20}$ Flow in the capillary beds is influenced predominantly by the characteristics of individual red cells and should be improved by inhibition of polymerisation and a reduced intracellular viscosity. The major effect of a higher total haemoglobin is on flow in larger vessels and is consequent on the raised viscosity. These observations support the concept that painful crises result principally from changes in larger vessel flow.

\section{A new hypothesis}

It is difficult to envisage a mechanism whereby skin cooling promotes multiple and symmetrical sites of vaso-occlusion, but this stimulus could induce a reflex shunting of blood away from the bone marrow with the same result of avascular necrosis. In healthy people skin cooling leads to cutaneous vasocon- striction with diversion of the blood to the deeper vessel systems ${ }^{25}$ in the muscles and bones. The extent to which these changes are accommodated by a fall in total limb flow or by a redistribution of blood flow within the limb is still unclear. There is evidence, however, that muscle blood flow is increased in response to skin cooling and it is assumed that some of the flow shunted away from the skin is accommodated by vessels within the muscle and bone marrow. In sickle cell disease the erythropoietic expansion is likely to be associated with increased bone marrow blood flow and there may be a limited capacity to accommodate further flow. Furthermore, if preferential channels in muscle open up and offer less resistance to flow than intramedullary vessels it is theoretically possible that these could compromise blood flow to the bone. Even small areas of bone marrow necrosis will induce an inflammatory response, increasing the intramedullary pressure and favouring a vascular bypass of the bone marrow. Such a shunting away from metabolically active areas is also supported by the increase in oxygen tension in the superfical veins of the forearm observed during the painful crisis. ${ }^{26}$

Peripheral blood flow in sickle cell disease is two to three times that in normal controls (Mohan JS, unpublished observations), and cardiac output is increased one and a half to two times, implying that a greater proportion of the cardiac output is diverted to the periphery. There is also some evidence that the vascular reflexes behave differently in sickle cell disease. $^{27} 28$

Because skin cooling does not induce bone marrow necrosis in other conditions with erythropoietic expansion such as $\beta$ thalassaemia or hereditary spherocytosis, cells containing $\mathrm{HbS}$ must play a part in the painful crisis but they may contribute to the process only after major blood flow shifts away from the marrow have occurred.

Several observations cast doubt on the traditional vaso-occlusive concept of the painful crisis. Centrally mediated reflexes, initiated by skin cooling and resulting in shunting of blood away from the bone marrow, could explain the commonly observed bilateral and symmetrical distribution. This is more consistent with the total haemoglobin effect on larger vessel flow, and they would be largely independent of the determinants of intravascular sickling. Such a "steal" syndrome is a hypothesis worthy of exploration because it may lead to new initiatives in the prevention and treatment of painful crises.

1 Charache S, Page DL. Infarction of bone marrow in the sickle disorders. Ann Intern Med 1967;67:1195-200.

2 Hammel CF, DeNardo GL, Lewis JP. Bone marrow and bone mineral scintigraphic studies in sickle cell disease. $B$ J Haematol 1973;25:593-8.

3 Hutchison RM, Merrick MV, White JM. Fat embolism in sickle cell disease. J Clin Pathol 1973;26:620-2.

4 Alavi A, Bond JP, Kuhl DE, Creech RH. Scan detection of bone marrow infarcts in sickle cell disorders. J Nucl Med 1974;15:1003-7.

5 Majd M, Frankel RS. Radionuclide imaging in skeletal inflammatory and ischemic disease in children. Radiology inflammatory and

6 Alavi A, Schumacher HR, Dorwart B, Kuhl DE. Bone marrow scan evaluation of arthropathy in sickle cell disorders. Arch Intern Med 1976;136:436-40. 
7 Redwood AM, Williams EM, Desai P, Serieant GR. Climate and painful crisis of sickle-cell disease in Jamaica. $\mathrm{Br}$ Med J 1976;i:66-8.

8 Diggs LW. Sickle cell crises. Am J Pathol 1975;44:1-19.

9 Addae SK. Mechanism for the high incidence of sickle-cell crisis in the tropical cool season. Lancet 1971 ;ii:1256.

10 Amjad H, Bannerman RM, Judisch JM. Sickling pain and season. Br Med J 1974;i:54.

11 Addae SK. Effect of acute temperature change on some renal functions in sickle cell disease. Afr J Med Sci 1971;2: 335-48.

12 Marsden PD, Shah KK. Artificially induced oedema in sickle cell anaemia. J Trop Med Hyg 1964;67:31-4.

13 Bainbridge R, Higgs DR, Maude GH, Serjeant GR. Clinical presentation of homozygous sickle cell disease. J Pediatr 1985;106:881-5.

14 Stevens MCG, Hayes RJ, Vaidya S, Serjeant GR. Fetal hemoglobin and clinical severity of homozygous sickle cell disease in early childhood. $J$ Pediatr 1981;98:37-41.

15 Serjeant GR. Sickle cell disease. Oxford: Oxford University Press, 1985.

16 Serjeant GR. Irreversibly sickled cells and splenomegaly in sickle-cell anaemia. Br J Haematol 1970;19:635-41.

17 Kar BC, Satapathy RK, Kulozik AE, Kulozik M, Sirr S, Serjeant BE, Serjeant GR. Sickle cell disease in Orissa Serjeant BE, Serjeant GR. Sickle cell

18 Perrine RP, Pembrey ME, John P, Perrine S, Shoup F. Natural history of sickle cell anemia in Saudi Arabs. A study of 270 subjects. Ann Intern Med 1978;88:1-6.

19 Powars DR, Schroeder WA, Weiss JN, Chan LS, Azen SP. Lack of influence of fetal hemoglobin levels or erythrocyte indices on the severity of sickle cell anemia. J Clin Invest
1980;65:732-40.

20 Baum KF, Dunn DT, Maude GH, Serjeant GR. The painful crisis of homozygous sickle cell disease: a study of risk factors. Arch Intern Med 1987;147:1231-4.

21 De Ceulaer K, Higgs DR, Weatherall DJ, Hayes RJ, Serjeant BE, Serjeant GR. Alpha-thalassemia reduces the hemolytic rate in homozygous sickle cell disease. $N$ Engl $J$ Med 1983;309:189-90.

22 Serjeant GR, Sommereux AM, Stevenson M, Mason K, Serjeant BE. Comparison of sickle cell-beta ${ }^{\circ}$ thalassaemia sickle cell-beta thalassaemia with homozygous sickle cell disease. $\mathrm{Br} J$ Haematol

23 Higgs DR, Aldridge BE, Lamb J, et al. The interaction of alpha-thalassemia and homozygous sickle-cell disease. $N$ Engl J Med 1982;306:1441-6.

24 Harkness DR, Roth S. Clinical evaluation of cyanate in sickle cell anemia. Prog Hematol 1975;9:157-84.

25 Roddie IC. Circulation to skin and adipose tissue. In: Field $\mathrm{J}$, ed. Handbook of physiology, Section 2, Volume III. Bethesda, Maryland: American Physiology Society: 1983:285-317.

26 Manfredi F, Spoto AP, Saltzman HA, Sieker HO. Studies of peripheral circulation during sickle-cell crisis. Circulation
1960;22:602-7.

27 Ward EE. In: Proceedings of 20th Scientific Meeting of Commonwealth Caribbean Medical Research Council, St Lucia. Kingston: University of the West Indies, 1975:1523

28 Hatch FE, Crowe LR, Miles DE, Young JP, Portner ME. Altered vascular reactivity in sickle hemoglobinopathy. A possible protective factor from hypertension. Am J Hypertension 1989;2:2-8. 